Wojciech MĘŻYK ${ }^{1}$, Piotr $\mathrm{CZECH}^{2}$

Opiekun naukowy: Piotr $\mathrm{CZECH}^{3}$

DOI: https://doi.org/10.53052/9788366249851.04

\title{
WPŁYW EKRANÓW AKUSTYCZNYCH ORAZ CZYNNIKÓW EKSPLOATACYJNYCH NA ODCZUWALNY KOMFORT JAZDY SAMOCHODEM OSOBOWYM
}

Streszczenie: Artykuł miał na celu przedstawienie wyników badań dotyczących wpływu ekranów akustycznych oraz wybranych czynników na hałas wewnątrz pojazdu. Obiektem badań był samochód osobowy. Pomiary wykonano w trakcie jazdy po nawierzchni asfaltowej oraz kostce brukowej. Zmierzono również hałas podczas postoju samochodu.

Słowa kluczowe: hałas, komfort jazdy, samochód osobowy

\section{INFLUENCE OF NOISE BARRIERS AND OPERATING FACTORS ON THE PERCEIVED COMFORT OF A PASSENGER CAR}

\begin{abstract}
Summary: The aim of the article was to present the research results regarding to the noise barriers the impact of the selected conditions on the noise inside the vehicle. The subject of the research was a passenger car. Measurements were made while driving on road surface made of asphalt and cobblestones. Noise was also measured when the car was not in motion.
\end{abstract}

Keywords: noise, driving comfort, passenger car

\section{Wprowadzenie}

Nieustanne dążenie człowieka do poprawy swoich warunków życia i pracy jest siłą napędową rozwoju cywilizacyjnego. Dążenia te nierozerwalnie wiążą się z rozwojem techniki. Z tego powodu tysiące lat temu wynaleziono koło, trzy wieki temu rozpoczęła się rewolucja przemysłowa trwająca właściwie do dnia dzisiejszego pod

${ }^{1}$ Politechnika Śląska, Wydział Transportu i Inżynierii Lotniczej, specjalność: eksploatacja pojazdów samochodowych

${ }^{2}$ Politechnika Śląska, Wydział Transportu i Inżynierii Lotniczej, email: piotr.czech@polsl.pl

3 Prof. dr hab. inż., Politechnika Śląska, Wydział Transportu i Inżynierii Lotniczej, email: piotr.czech@polsl.pl 
postacią tzw. IV rewolucji przemysłowej. Rozwój techniki każdorazowo pociąga za sobą również rozwój transportu. Konieczność przemieszczania ludzi, dostarczania surowców i poszukiwania rynków zbytu zaowocowały rozwojem rozmaitych środków przemieszczania. Rozwój ten, wszakże dobry i pożyteczny, przyczyniający się do poprawy życia ludzkiego, niesie za sobą również negatywne konsekwencje. Zanieczyszczenie środowiska, emisja szkodliwych substancji oraz zwiększenie poziomu hałasu. Uciążliwy hałas zauważalny jest głównie dla mieszkańców dużych miast, sąsiedztwa dużych zakładów przemysłowych i portów lotniczych. Jak wykazały badania, jednym z głównych źródeł hałasu jest transport kołowy. Duża liczba przemieszczających się po drogach pojazdów sprawia, że jest to obecnie bardzo duży problem. Hałas uciążliwy jest nie tylko dla ludzi obserwujących ruch pojazdów z zewnątrz, czy też żyjących w sąsiedztwie traktów komunikacyjnych, ale i dla samych kierowców, nierzadko spędzających długie godziny w podróży. Dlatego też producenci nieustannie starają się obniżać hałas odczuwany w pojeździe. Jest to bardzo ważne, gdyż hałas działający na kierowcę to nie tylko uciążliwość. Powoduje on zmęczenie, znużenie i obniża koncentrację kierującego, a tym samym bezpieczeństwo jazdy i zwiększa ryzyko popełnienia przez niego błędu mogącego skutkować wypadkiem lub kolizją. Dlatego też hałas odczuwalny wewnątrz pojazdu został wybrany za temat niniejszego artykułu.

\section{Zagadnienia teoretyczne}

Hałas jest to każdy uciążliwy dla ludzi dźwięk, który przy dłuższej ekspozycji oraz w zależności jego parametrów takich jak widmo częstotliwości składowych, natężenie czy też zmienność w czasie może powodować długo lub krótkotrwałe uszkodzenia w organizmie człowieka. Hałas powstaje na skutek mieszania się różnych dźwięków, które nakładają się na siebie i zniekształcają w sposób chaotyczny [1].

Istnieje kilka kryteriów podziału hałasu. Ze względu na zmiany jego natężenia w czasie można wyróżnić:

- hałas ustalony,

- hałas nieustalony,

- hałas impulsowy.

Hałas ustalony występuje wtedy, gdy w czasie obserwacji poziom dźwięku nie zmienia się o więcej niż $5 \mathrm{~dB}$. Jest to np. hałas wynikający z pracy silnika. Hałas nieustalony z kolei występuje, gdy zmiany poziomu dźwięku są wyższe niż $5 \mathrm{~dB}$. Ma to miejsce np. wtedy, gdy mikrofon ustawiony jest na zewnątrz pojazdu, który koło niego przejeżdża. Wówczas w zależności od położenia pojazdu względem mikrofonu rejestrowany poziom dźwięku zmienia się w znacznym stopniu. Z hałasem impulsowym mamy z kolei do czynienia, gdy występuje wiele impulsów o wysokiej wartości ciśnienia akustycznego, ale trwających mniej niż 1 sekundę. Może on wstępować np. podczas wystrzału z broni palnej [2].

Kolejny podział dotyczy częstotliwości hałasu. Podobnie jak w przypadku dźwięku wyróżnić można hałas infradźwiękowy, ultradźwiękowy i słyszalny. Hałas infradźwiękowy występuje, gdy jego widmo składa się z częstotliwości od 1-20 Hz, oraz częstotliwości słyszalnych do $50 \mathrm{~Hz}$. Hałas ultradźwiękowy powstaje, gdy jego widmo składa się z częstotliwości od $10 \mathrm{kHz}$ do $40 \mathrm{kHz}$. Hałas słyszalny z kolei 
powstaje, gdy w jego widmie dominują częstotliwości słyszalne dla człowieka, czyli ok. $20 \mathrm{~Hz}-20 \mathrm{kHz}$ [2].

Poziom dźwięku jest parametrem wyrażonym w skali logarytmicznej informujący o wielkości amplitudy zmiany ciśnienia. Jako, że ucho ludzkie ma możliwość rejestracji dźwięku od amplitudy $20 \mu \mathrm{Pa}$ do ok. $100000000 \mu \mathrm{Pa}$ w celu usprawnienia badań i obliczeń zastosowano skalę logarytmiczną. Dużą zaletą zastosowania skali decybelowej jest wierność odtworzenia postrzegania dźwięku przez ucho ludzkie. Względna zmiana poziomu dźwięku o $1 \mathrm{~dB}$ jest postrzegana tak samo niezależnie od jego wartości początkowej. Najmniejsza zmiana, jakie ucho ludzkie może zarejestrować wynosi $3 \mathrm{~dB}$, a zmiana o $10 \mathrm{~dB}$ wywołuje subiektywne wrażenie podwojenia głośności. Warto jednak zauważyć, że ucho ludzkie ma różną czułość dla różnych częstotliwości dźwięku, z czego największą w zakresie 2-5 kHz, co przekłada się na różne wrażenia słuchowe [3].

Pracy podzespołów pojazdu samochodowego nieustannie towarzyszy hałas. Nawet, gdy samochód nie przemieszcza się, a jego silnik jest uruchomiony generuje on określone dźwięki. Głównymi źródłami hałasu odczuwanymi wewnątrz pojazdu są [4]:

- $\quad$ odgłosy związane z toczeniem się kół po nawierzchni drogi,

- praca silnika i układu przeniesienia napędu,

- $\quad$ odgłosy zasysania powietrza i wydechu,

- drgania przewodów paliwowych,

- odgłos wentylatora układu chłodzenia i dmuchawy ogrzewania,

- odgłosy pochodzące od zawirowań powietrza wokół samochodu,

- odgłosy pochodzące z układu zawieszenia pojazdu,

- drgania silnika i układu napędowego przenoszone na nadwozie,

- drgania karoserii i elementów wykończenia wnętrza.

W celu wygłuszenia pojazdu stosuje się specjalne maty wygłuszające (montowane wewnątrz pojazdu) oraz masy (na zewnątrz pojazdu oraz w profilach zamkniętych). Wśród mat wygłuszających wyróżnić można następujące grupy [5, 6]:

- fonoizolacyjne,

- dźwiękochłonne,

- tłumiące.

W motoryzacji wykorzystuje się również systemy aktywnej redukcji hałasu ANC (ang. Active Noise Control). Ich działanie polega na wyemitowaniu fali w przeciwfazie do fali dźwiękowej stanowiącej hałas i na skutek interferencji obniżenia poziomu dźwięku [7, 8].

Zgodnie z normą PN-90/S-04052 dopuszczalny poziom hałasu wewnętrznego pojazdów po 1994 roku wynosi 79 dB(A). Norma ta precyzuje również szczegółowo sposób przeprowadzenia pomiarów, liczbę oraz rozmieszczenie punktów pomiarowych dla różnych typów pojazdów oraz warunki, w jakich pomiary powinny być wykonywane.

\section{Opis badań}

Celem głównym przeprowadzonych badań była ocena wpływu zamontowanych przy drodze ekranów akustycznych na odczuwalny wewnątrz pojazdu hałas. Dodatkowo sprawdzono wpływ innych wybranych czynników na komfort podróży samochodem. 
Obiektem badań był samochód osobowy Mazda CX-5. Podstawowe parametry wybranego do badań samochodu zostały zestawione w tabeli 1.

Tabela 1. Dane techniczne badanego samochodu

\begin{tabular}{|c|c|}
\hline Marka & Mazda \\
\hline Model & CX-5 \\
\hline Rok produkcji & 2015 \\
\hline Przebieg & $89000 \mathrm{~km}$ \\
\hline Typ nadwozia & SUV \\
\hline Pojemność skokowa silnika & $1998 \mathrm{~cm}^{3}$ \\
\hline Układ konstrukcyjny silnika & $\mathrm{R} 4$ \\
\hline Rodzaj paliwa & Benzyna \\
\hline Rodzaj układu wtryskowego & Bezpośredni \\
\hline Moc maksymalna & $118 \mathrm{~kW}$ przy $6000 \mathrm{obr} / \mathrm{min}$ \\
\hline Maksymalny moment obrotowy & $208 \mathrm{Nm}$ przy $4000 \mathrm{obr} / \mathrm{min}$ \\
\hline Typ skrzyni biegów & Manualna 6 biegowa \\
\hline Zawieszenie przednie & Kolumna MacPhersona \\
\hline Zawieszenie tylne & $\begin{array}{c}\text { Niezależne, z wahaczami } \\
\text { poprzecznymi }\end{array}$ \\
\hline Typ napędu & Przód, z dołączanym tylnym \\
\hline Marka ogumienia & Nokian \\
\hline Model ogumienia & Weatherproof SUV \\
\hline Rozmiar opon & $225 / 65 \mathrm{R} 17$ \\
\hline Indeks nośności & 106 \\
\hline Indeks prędkości & $\mathrm{H}$ \\
\hline
\end{tabular}

W trakcie badań mierzono poziom hałasu wewnątrz samochodu w dwóch punktach pomiarowych. Pierwszy znajdował się przy fotelu kierowcy, a drugi na środku tylnych siedzeń samochodu w jego osi symetrii. Mikrofon w każdym z przypadków był umieszczony na wysokości ok. $700 \mathrm{~mm}$ względem siedziska. Miejsce umieszczenia mikrofonu wybrano zgodnie z normą PN-90/S-04052.

Pomiarów zostały wykonane z użyciem całkującego miernika Brüel\&Kjaer 2250, który spełnia normy IEC 61672-1:2002 oraz IEC 61260:1995 dla 1 klasy dokładności. W pomiarach wykorzystano krzywą korekcyjną A oraz charakterystyką dynamiczną F.

Pomiarów dokonywano w trakcie ruchu pojazdu oraz na postoju przy załączonym silniku. Badania przeprowadzano dla rozgrzanego wcześniej silnika.

W trakcie przeprowadzonych na drogach eksperymentów samochód poruszał się z prędkością od $50 \mathrm{~km} / \mathrm{h}$ do $140 \mathrm{~km} / \mathrm{h}$ - dla dróg o nawierzchni z asfaltobetonu, oraz $50 \mathrm{~km} / \mathrm{h}$ dla nawierzchni z kostki granitowej.

Na rysunku 1 pokazano odcinek drogi, na którym realizowane były pomiary hałasu wewnątrz samochodu poruszającego się w zakresie prędkości od $50 \mathrm{~km} / \mathrm{h}$ do $80 \mathrm{~km} / \mathrm{h}$, a na rysunku 2 wygląd nawierzchni drogi.

Sprawdzono również wpływ włączenia dmuchawy ogrzewania na hałas odczuwalny wewnątrz poruszającego się z prędkością $50 \mathrm{~km} / \mathrm{h}$ samochodu. Zmierzono również hałas podczas postoju pojazdu z załączoną jak i wyłączoną dmuchawą ogrzewania. W trakcie tego typu badań dmuchawa ogrzewania była ustawiona na najwyższy biegu. 
Ponadto na części odcinka drogi, na którym realizowano badania zainstalowane były ekrany dźwiękochłonne. Dla samochodu poruszającego się z prędkością $50 \mathrm{~km} / \mathrm{h}$ i $60 \mathrm{~km} / \mathrm{h}$ zmierzono hałas podczas przejazdu pomiędzy ekranami przy otwartym oknie pasażera. Na rysunku 3 przedstawiono odcinek drogi z ekranami akustycznymi.

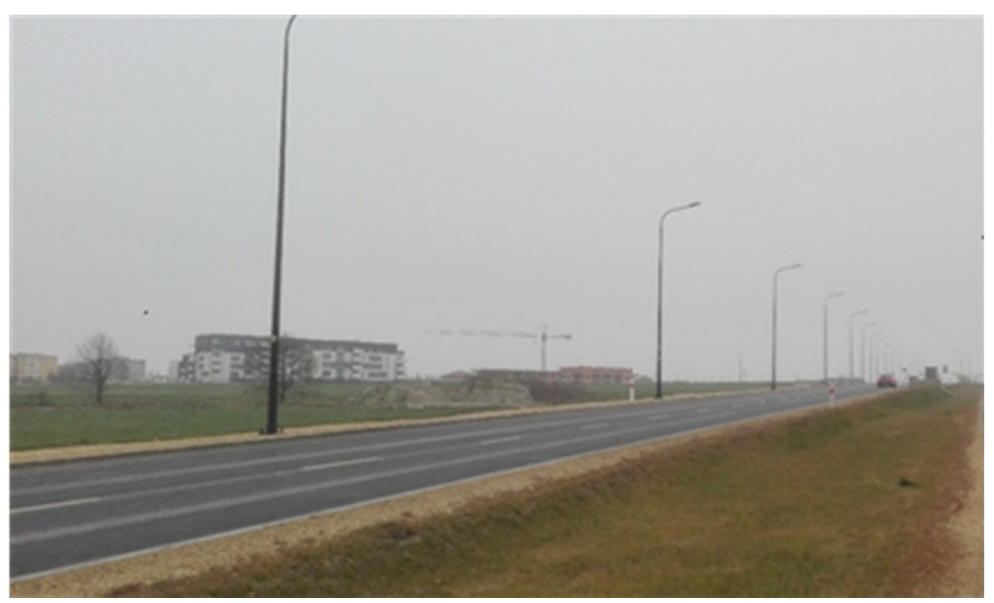

Rysunek 1. Odcinek drogi wykorzystany w trakcie badań drogowych

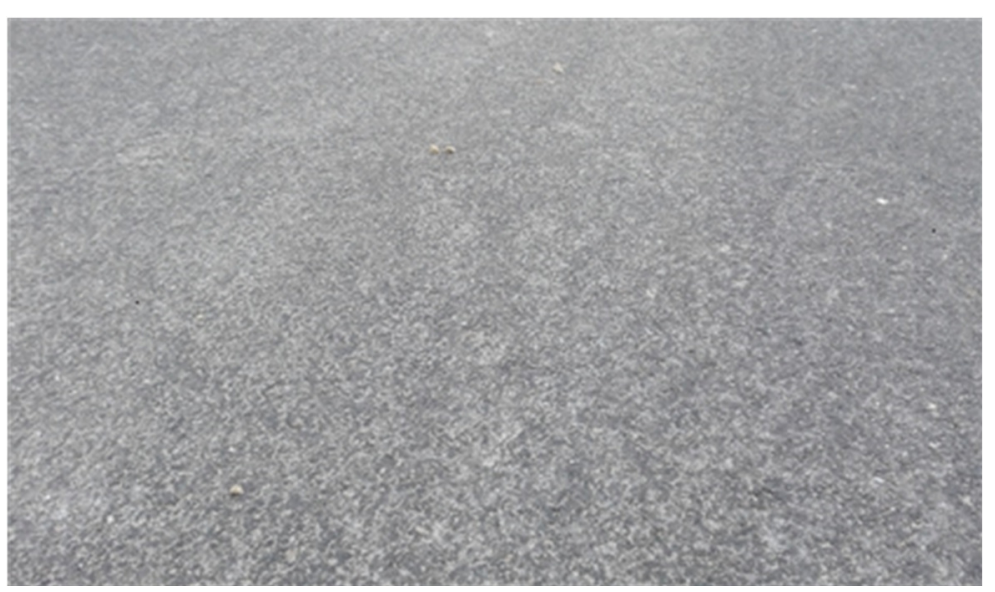

Rysunek 2. Nawierzchnia drogi wykorzystanej w trakcie badań drogowych 


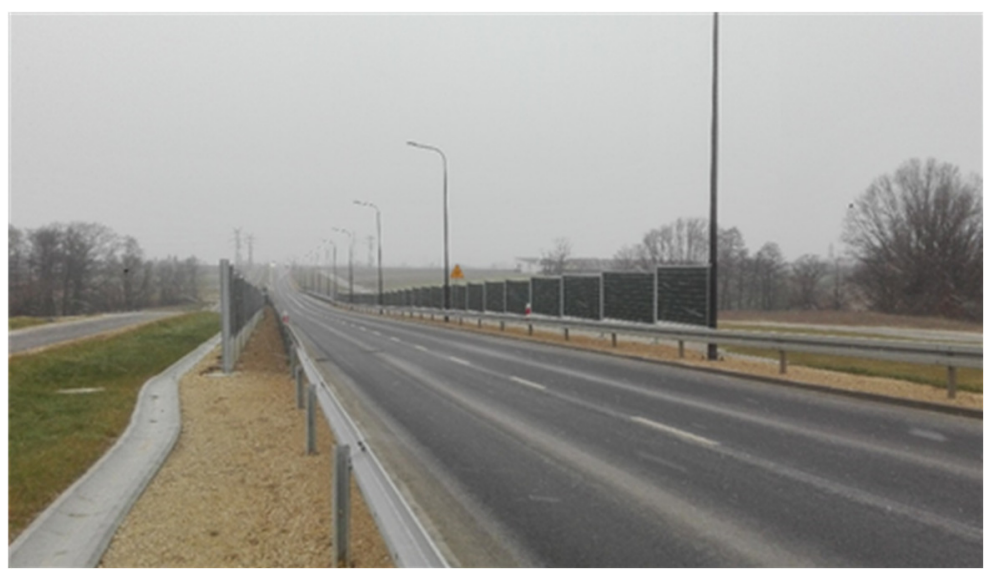

Rysunek 3. Ekrany akustyczne zainstalowane na badanym odcinku drogi

W trakcie badań nawierzchnia była lekko wilgotna, a temperatura powietrza wynosiła ok. $4^{\circ} \mathrm{C}$.

Pomiary wykonywano trzykrotnie, a w przypadku wystąpienia różnicy większej od $2 \mathrm{~dB}$ pomiędzy zmierzonymi wartościami, pomiary powtarzano.

Obiekt badań miał ważne badania techniczne, a sterownik silnika nie zarejestrował żadnych błędów.

\section{Analiza wyników badań}

W tabeli 2 oraz na rysunku 4 zestawiono uśrednione z 3 pomiarów wartości równoważnego poziomu hałasu podczas jazdy samochodu z różnymi prędkościami po nawierzchni asfaltobetonowej przy wyłączonej dmuchawie ogrzewania.

Tabela 2. Wartości średnie poziomu hałasu podczas jazdy samochodu z różnymi prędkościami przy wytaczonej dmuchawie ogrzewania

\begin{tabular}{|c|c|c|c|c|}
\hline & \multicolumn{4}{|c|}{ LAeq dB } \\
\hline Prędkość km/h & \multicolumn{4}{|c|}{ Pomiar } \\
\cline { 2 - 5 } & $\begin{array}{c}\text { z przodu przy } \\
\text { zamkniętym } \\
\text { oknie }\end{array}$ & $\begin{array}{c}\text { z przodu przy } \\
\text { otwartym oknie }\end{array}$ & $\begin{array}{c}\text { z tyłu przy } \\
\text { zamkniętym } \\
\text { oknie }\end{array}$ & $\begin{array}{c}\text { z tyłu przy } \\
\text { otwartym oknie }\end{array}$ \\
\hline 50 (bieg 4) & 58,2 & 61,8 & 57,4 & 59,2 \\
\hline 60 (bieg 4) & 59,3 & 63,9 & 59,7 & 61,6 \\
\hline 60 (bieg 5) & 60,4 & 64,3 & 59,9 & 61,7 \\
\hline 70 (bieg 5) & 61,7 & 67,4 & 61,1 & 63,6 \\
\hline 80 (bieg 5) & 63,4 & 69,5 & 64,1 & 67,4 \\
\hline
\end{tabular}




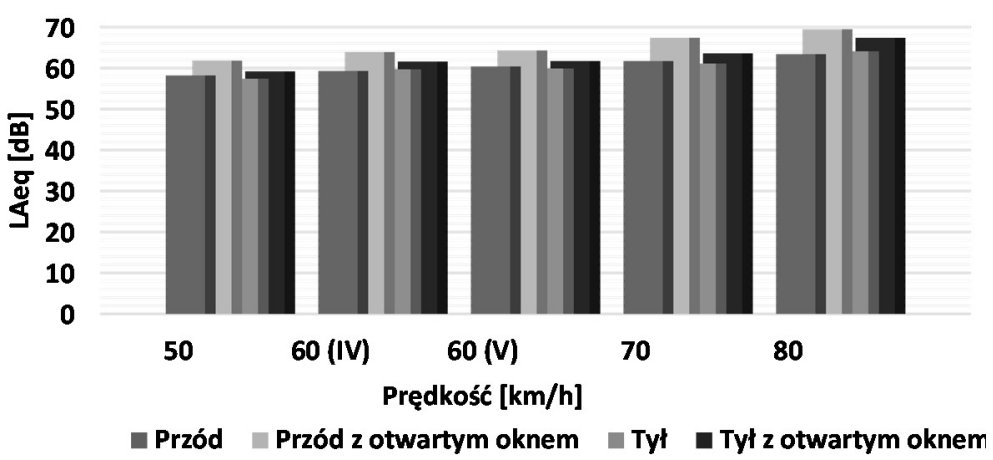

Rysunek 4. Wartości średnie poziomu hałasu podczas jazdy samochodu z różnymi prędkościami przy wytaczonej dmuchawie ogrzewania

Analiza danych pozwala zauważyć, że hałas zarejestrowany z przodu jak i z tyłu samochodu przy zamkniętych oknach utrzymuje się na podobnym poziomie niezależnie od prędkości jazdy. Największa różnica wynosi ok. 1,2 dB. Można również zauważyć, że podczas jazdy z prędkością $60 \mathrm{~km} / \mathrm{h}$, wyższy poziom hałasu odnotowywany był dla jazdy na biegu 5 niż 4 . Wynikać to może z tego, iż jest to zbyt wysoki bieg w stosunku do prędkości jazdy. Otwarcie okna powoduje zauważalny wzrost poziomu hałasu, tym wyższy im większa jest prędkość jazdy. Hałas panujący z tyłu pojazdu jest niższy niż obserwowany na miejscu kierowcy, co spowodowane jest większym oddaleniem od źródła hałasu.

W tabeli 3 oraz na rysunku 5 zestawiono uśrednione z 3 pomiarów wartości równoważnego poziomu hałasu zarejestrowane $\mathrm{w}$ trakcie postoju samochodu. W trakcie eksperymentu silnik pracował na biegu jałowym. Celem badań było porównanie odczuwanego przez pasażerów i kierowcę poziomu hałasu w trakcie postoju pojazdu oraz ocena wpływu uruchomienia dmuchawy ogrzewania na odczuwany hałas. Dmuchawa była załączana na najwyższym przełożeniu.

Tabela 3. Wartości średnie poziomu hałasu podczas postoju samochodu przy wytaczonej $i$ zataczonej dmuchawie ogrzewania

\begin{tabular}{|c|c|c|c|c|}
\hline & \multicolumn{4}{|c|}{ LAeq dB } \\
\hline \multirow{2}{*}{$\begin{array}{c}\text { Dmuchawa } \\
\text { ogrzewania }\end{array}$} & $\begin{array}{c}\text { z przodu przy } \\
\text { zamkniętym } \\
\text { oknie }\end{array}$ & $\begin{array}{c}\text { z przodu przy } \\
\text { otwartym oknie }\end{array}$ & $\begin{array}{c}\text { z tyłu przy } \\
\text { zamkniętym } \\
\text { oknie }\end{array}$ & $\begin{array}{c}\text { z tyłu przy } \\
\text { otwartym oknie }\end{array}$ \\
\hline wyłączona & 41,4 & 43,3 & 40,2 & 43,0 \\
\hline załączona & 61,4 & 61,5 & 57,9 & 57,5 \\
\hline
\end{tabular}




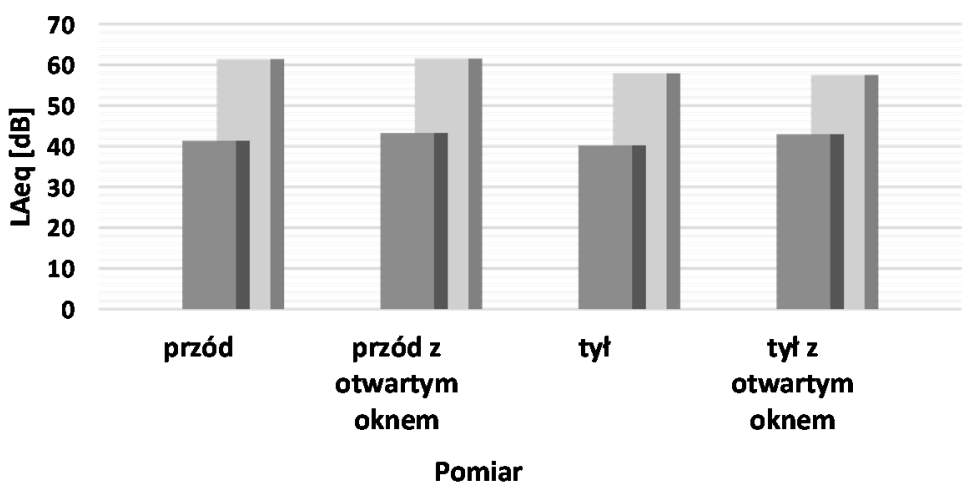

Wyłączona dmuchawa ogrzewania Załączona dmuchawa ogrzewania

Rysunek 5. Wartości średnie poziomu hałasu podczas postoju samochodu przy wytaczonej i załaczonej dmuchawie ogrzewania

Włączenie dmuchawy powoduje znaczny wzrost hałasu wewnątrz pojazdu. Zarejestrowany z przodu pojazdu wzrósł o ok. $20 \mathrm{~dB}$, natomiast zarejestrowany z tyłu o ok. 16-17 dB. Wynika z tego, że im dalej od źródła hałasu, tym jego wpływ na odczuwalny hałas jest niższy. Widać również, że po załączeniu dmuchawy znacząco zmalał wpływ hałasu zewnętrznego odczuwalnego po otwarciu okna, gdyż został on zagłuszony przez działającą dmuchawę ogrzewania.

Celem kolejnych przeprowadzonych eksperymentów było porównanie odczuwanego przez pasażerów i kierowcę poziomu hałasu podczas jazdy samochodem z tą samą prędkością po różnych typach nawierzchni drogi. W trakcie badań pojazd poruszał się $\mathrm{z}$ prędkością $50 \mathrm{~km} / \mathrm{h}$ po drodze o nawierzchni wykonanej $\mathrm{z}$ asfaltobetonu oraz $\mathrm{z}$ kostki granitowej.

W tabeli 4 oraz na rysunku 6 zestawiono uśrednione z 3 pomiarów wartości równoważnego poziomu hałasu podczas jazdy samochodu po nawierzchni asfaltobetonowej oraz brukowej przy wyłączonej dmuchawie ogrzewania.

Tabela 4. Wartości średnie poziomu hałasu podczas jazdy samochodu z prędkościa $50 \mathrm{~km} / \mathrm{h}$ przy wytaczonej dmuchawie ogrzewania

\begin{tabular}{|c|c|c|c|c|}
\hline & \multicolumn{4}{|c|}{ LAeq dB } \\
\hline \multirow{2}{*}{$\begin{array}{c}\text { Dmuchawa } \\
\text { ogrzewania }\end{array}$} & $\begin{array}{c}\text { z przodu } \\
\text { przy } \\
\text { zamkniętym } \\
\text { oknie }\end{array}$ & $\begin{array}{c}\text { z przodu przy } \\
\text { otwartym oknie }\end{array}$ & $\begin{array}{c}\text { z tyłu przy } \\
\text { zamkniętym } \\
\text { oknie }\end{array}$ & $\begin{array}{c}\text { z tyłu przy } \\
\text { otwartym oknie }\end{array}$ \\
\hline wyłączona & 63,5 & 64,9 & 61,2 & 61,7 \\
\hline załączona & 58,2 & 61,8 & 57,4 & 59,2 \\
\hline
\end{tabular}




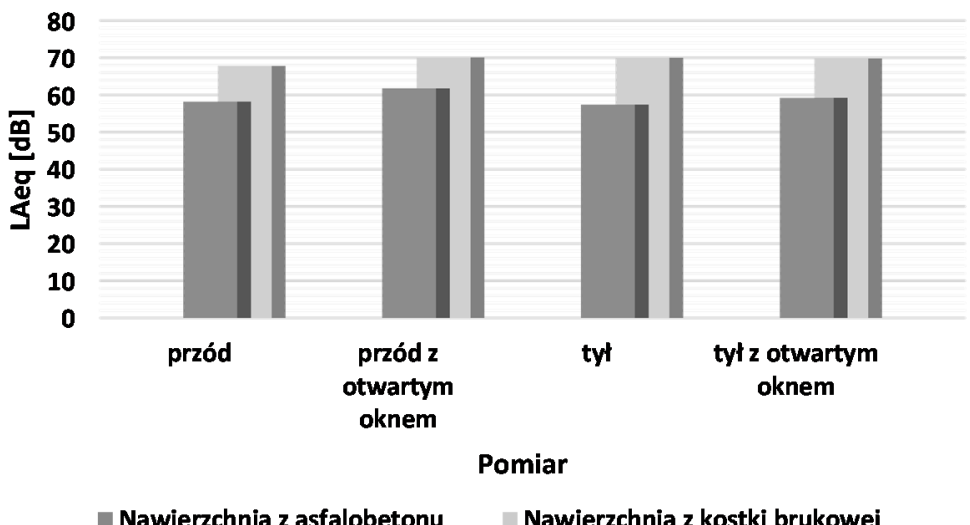

Rysunek 6. Wartości średnie poziomu hałasu podczas jazdy samochodu z prędkościa $50 \mathrm{~km} / \mathrm{h}$ przy wytaczonej dmuchawie ogrzewania

Zarejestrowane dane pozwalają stwierdzić, że jazda samochodu na nawierzchni wykonanej z kostki granitowej powoduje znaczący wzrost poziomu hałasu odczuwalnego wewnątrz, w porównaniu z jazdą z tą samą prędkością po nawierzchni asfaltobetonowej. Zarejestrowana z przodu pojazdu różnica wynosi ok. 9-10 dB, a z tyłu ok. $13 \mathrm{~dB}$. Można również zauważyć, że podczas jazdy po nawierzchni wykonanej $\mathrm{z}$ asfaltobetonu po otwarciu okna również następuje wzrost poziomu hałasu. Dla badań wykonanych na nawierzchni z kostki granitowej, jedyna różnica następuje przy pomiarze $\mathrm{z}$ przodu pojazdu. Z kolei hałas zarejestrowany z tyłu oraz z przodu pojazdu przy otwartym oknie przyjmuje bardzo podobne wartości.

W kolejnej części badań zestawiono pomiary zebrane podczas jazdy samochodu ze stałą prędkością wynoszącą $50 \mathrm{~km} / \mathrm{h}$ przy załączonej i wyłączoną dmuchawie ogrzewania.

W tabeli 5 oraz na rysunku 7 zestawiono uśrednione z 3 pomiarów wartości równoważnego poziomu hałasu podczas jazdy samochodu po nawierzchni asfaltobetonowej przy wyłączonej i załączonej dmuchawie ogrzewania. W trakcie badań dmuchawa pracowała z największą możliwą mocą.

Tabela 5. Wartości średnie poziomu hałasu podczas jazdy samochodu z prędkościa $50 \mathrm{~km} / \mathrm{h}$ na nawierzchni z asfalobetonu

\begin{tabular}{|c|c|c|c|c|}
\hline & \multicolumn{4}{|c|}{ LAeq dB } \\
\hline \multirow{2}{*}{$\begin{array}{c}\text { Nawierzchnia } \\
\text { drogi }\end{array}$} & $\begin{array}{c}\text { z przodu } \\
\text { przy } \\
\text { zamkniętym } \\
\text { oknie }\end{array}$ & $\begin{array}{c}\text { z przodu przy } \\
\text { otwartym oknie }\end{array}$ & $\begin{array}{c}\text { z tyłu przy } \\
\text { zamkniętym } \\
\text { oknie }\end{array}$ & $\begin{array}{c}\text { z tyłu przy } \\
\text { otwartym oknie }\end{array}$ \\
\hline asfalobeton & 58,2 & 61,8 & 57,4 & 59,2 \\
\hline kostka brukowa & 67,8 & 70,1 & 70 & 69,8 \\
\hline
\end{tabular}




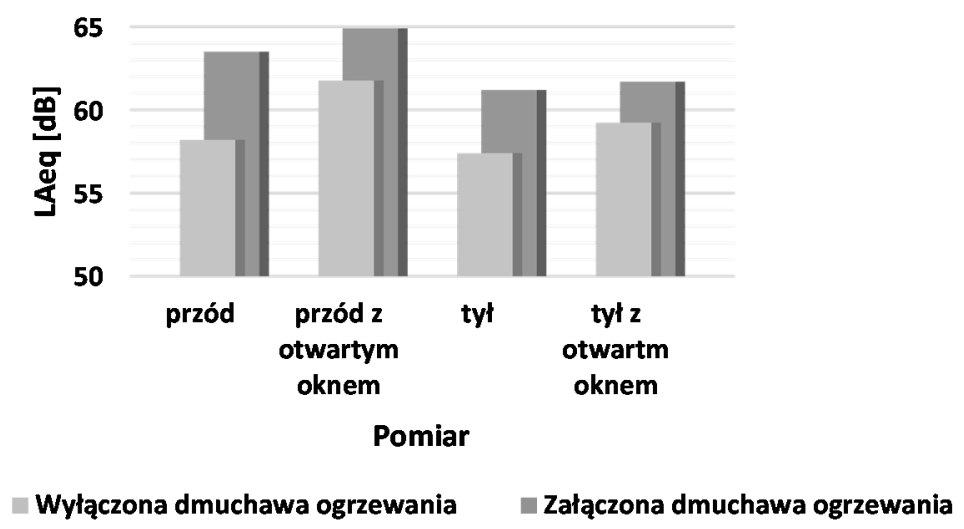

Rysunek 7. Wartości średnie poziomu hałasu podczas jazdy samochodu z prędkościa $50 \mathrm{~km} / \mathrm{h}$ na nawierzchni z asfalobetonu

Analizując otrzymane dane można zauważyć, że uruchomienie dmuchawy ogrzewania powoduje wzrost odczuwanego hałasu wewnątrz samochodu o ok. $5 \mathrm{~dB}$ dla pomiarów wykonanych z przodu i ok. $4 \mathrm{~dB}$ z tyłu pojazdu. Po otwarciu przedniego okna hałas wzrasta o ok. $3 \mathrm{~dB}$ dla pomiarów realizowanych z przodu i o $1 \mathrm{~dB}$ dla pomiarów wykonanych z tyłu. Można zauważyć, że po włączeniu dmuchawy hałas na miejscu kierowcy jest porównywalny z występującym podczas jazdy z prędkością $80 \mathrm{~km} / \mathrm{h}$, a na miejscach tylnych z tym, który występuje podczas jazdy samochodu z prędkością $70 \mathrm{~km} / \mathrm{h}$ z wyłączoną dmuchawą ogrzewania.

Kolejna część badań została poświęcona ekranom akustycznych budowanym przy drogach o dużym natężeniu ruchu. Do badań wybrano odcinek drogi, na którym w jego części zostały zainstalowane ekrany akustyczne. Ich celem jest ograniczenie poziomu hałasu odczuwalnego w sąsiedztwie drogi. Odbijają one i częściowo pochłaniają fale dźwiękowe ograniczając ich przedostawanie się na druga stronę przegrody.

W tabeli 6 oraz na rysunku 8 zestawiono uśrednione z 3 pomiarów wartości równoważnego poziomu hałasu podczas jazdy samochodu po nawierzchni asfaltobetonowej przy wyłączonej dmuchawie ogrzewania. W pojeździe dodatkowo otwarto okna podczas przejazdu pomiędzy ekranami akustycznymi oraz na otwartej przestrzeni otoczonej polami i łąkami.

Tabela 6. Wpływ ekranów akustycznych na poziom hałasu w samochodzie poruszajacym się po nawierzchni $z$ asfalobetonu przy wyłaczonej dmuchawie ogrzewania

\begin{tabular}{|c|c|c|c|}
\hline & & \multicolumn{2}{|c|}{ LAeq dB } \\
\hline Pomiar & $\begin{array}{c}\text { Prędkość jazdy } \\
\mathrm{km} / \mathrm{h}\end{array}$ & \multicolumn{2}{|c|}{ Pomiar } \\
\cline { 3 - 4 } & & $\begin{array}{c}\text { z przodu przy } \\
\text { otwartym oknie }\end{array}$ & $\begin{array}{c}\text { z tyłu przy } \\
\text { otwartym oknie }\end{array}$ \\
\hline na otwartej przestrzeni & 50 & 61,8 & 59,2 \\
\hline przejazd między ekranami & 50 & 64,8 & 60,7 \\
\hline na otwartej przestrzeni & 60 & 64,3 & 61,7 \\
\hline przejazd między ekranami & 60 & 66,7 & 62,4 \\
\hline
\end{tabular}




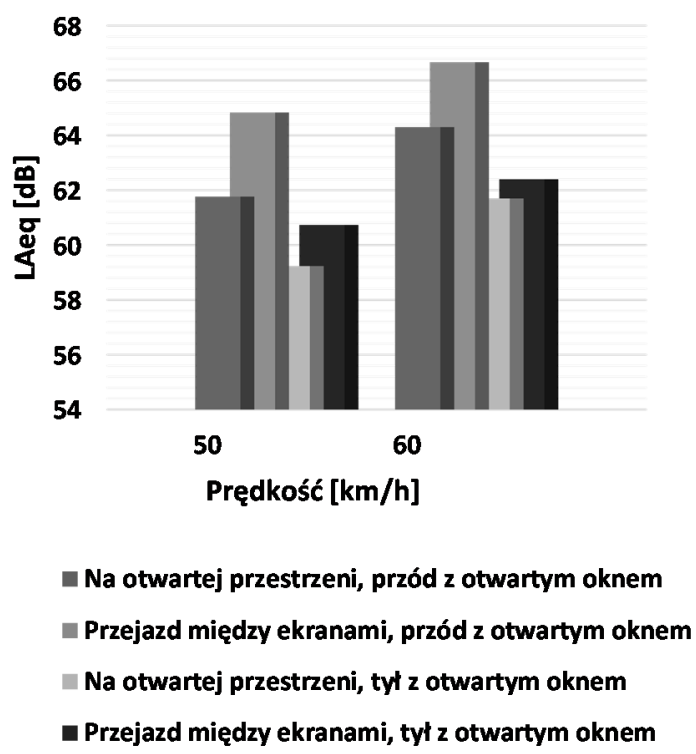

Rysunek 8. Wptyw ekranów akustycznych na poziom hałasu w samochodzie poruszającym się po nawierzchni z asfalobetonu przy wytaczonej dmuchawie ogrzewania

Jak można zauważyć na podstawie analizy zarejestrowanych pomiarów, przejazd pomiędzy ekranami akustycznymi powoduje wzrost odczuwalnego poziomu hałasu przez pasażerów i kierowcę samochodu. Wynika to z faktu, iż ekrany ograniczają rozchodzenie się dźwięku wokół drogi i powodują jego zatrzymanie pomiędzy nimi. Skutkuje to zwiększeniem poziomu hałasu o ok. $3 \mathrm{~dB}$ przy rejestracji z przodu pojazdu, oraz ok. $1 \mathrm{~dB}$ na miejscach tylnych. Efekt ten wyraźny był zwłaszcza przy niższej prędkości, gdzie różnica w odczuwalnym hałasie w stosunku do jazdy na otwartej przestrzeni była wyższa. Ponadto można zauważyć, że im dalej od otwartego okna w samochodzie tym wpływ ekranów był zauważalnie mniejszy.

\section{Podsumowanie badań}

Z przeprowadzonych badań można wysunąć następujące wnioski:

- $\quad$ hałas wewnątrz pojazdu wzrasta wraz ze wzrostem prędkości jazdy;

- otwarcie okna powoduje wzrost odczuwanego poziomu hałasu o ok. 2-8 dB, a wpływ ten jest wyraźniejszy dla wyższych prędkości jazdy, oraz bardziej odczuwalny z przodu aniżeli z tyłu pojazdu;

- włączenie dmuchawy ogrzewania podczas pomiarów na biegu jałowym wywołało znaczący wzrost poziomu hałasu, o ok. $20 \mathrm{~dB}$ z przodu i $17 \mathrm{~dB}$ z tyłu pojazdu;

- $\quad$ przejazd po nawierzchni z kostki granitowej wywołał wzrost poziomu hałasu o ok. $10 \mathrm{~dB}$ z przodu i $13 \mathrm{~dB}$ z tyłu w porównaniu do jazdy z tą samą prędkością po nawierzchni asfaltobetonowej;

- $\quad$ uruchomienie dmuchawy w czasie jazdy z zamkniętymi oknami spowodowało wzrost poziomu hałasu na miejscach przednich o ok. $5 \mathrm{~dB}$, a tylnych o ok. $3 \mathrm{~dB}$; 
- $\quad$ uruchomienie dmuchawy podczas jazdy z otwartymi oknami powoduje, że hałas jest odczuwalny praktycznie tylko dla prędkości $60 \mathrm{~km} / \mathrm{h}$, a dla wyższych prędkości staje się niezauważalny, co dowodzi, że przy wyższych prędkościach główne źródło hałasu stanowi hałas opływu powietrza i toczenia kół;

- $\quad$ zarejestrowany poziom hałasu mieści się w założonej normą granicy, a został on przekroczony tylko raz, podczas pomiarów przy otwartym oknie przy prędkości $140 \mathrm{~km} / \mathrm{h}$, ale były to warunki pomiaru nieuwzględnione w normie;

- $\quad$ przejazd między ekranami akustycznymi spowodował wzrost poziomu hałasu odczuwalnego wewnątrz samochodu o ok. 1-3 dB, co dowodzi, że ekrany zatrzymują dźwięk w obszarze jezdni ograniczając jego przedostawanie się wokół drogi.

Na podstawie przeprowadzonych badań jednoznacznie można zauważyć, jak wiele czynników ma wpływ na hałas odczuwany wewnątrz pojazdu podczas jazdy.

\section{LITERATURA}

1. Serwis internetowy Encyklopedia PWN - Hałas: https://encyklopedia.pwn.pl/ haslo/halas;3909720.html.

2. Serwis internetowy Encyklopedia zarządzania - Hałas: https://mfiles.pl/pl/ index.php/Ha\%C5\%82as.

3. Materiały firmy Brüel\&Kjaer - Pomiary dźwięków: http://dydaktyka.polsl.pl /ROZ5/aboczkowski/Dokumenty/Diagnozowanie\%20i\%20Monitorowanie\%20S ystem\%C3\%B3w\%20Technicznych/01.Pomiar_Dzwieku.pdf.

4. JĘDRYSKO W., ŁAZARZ B., CZECH P., MATYJA T., WITASZEK M.: Oddziaływanie hałasu na kierowcę i pasażerów w samochodach osobowych. TTS, 12(2015), 730-736.

5. Serwis internetowy WP Autokult - Poznaj najnowsze materiały i technologie wygłuszania samochodu: https://autokult.pl/26485,poznaj-najnowszetechnologie-i-materialy-wygluszania-samochodu.

6. ZIELIŃSKI A.: Konstrukcja nadwozi samochodów osobowych i pochodnych. WKŁ, Warszawa 2003.

7. Serwis internetowy WP Autokult - Cicho sza! Metody aktywnej redukcji hałasu w samochodzie: https://autokult.pl/6943,cicho-sza-metody-aktywnej-redukcjihalasu-w-samochodzie.

8. ELLIOTT S.J.: A review of active noise and vibration control in road vehicles. ISVR Technical Memorandum, 981(December 2008), 1-25. ISVR Institute of Sound and Vibration Research. University of Southampton. 